\section{SAT0220 USE OF TOCILIZUMAB IN AORTITIS. A MULTICENTER STUDY OF 79 PATIENTS}

Monica Calderón-Goercke, J. Loricera, D. Prieto-Peña, Vicente Aldasoro, Santos Castañeda, Ignacio Villa-Blanco, Alicia Humbría, Clara Moriano, Susana Romero-Yuste, J. Narváez, Catalina Gomez-Arango, Eva Perez-Pampín, Rafael Melero, Marcelino Revenga, Noelia Alvarez-Rivas, Francisca Sivera, María Álvarez del Buergo, Luisa Marena Rojas, Eva Galindez, Beatriz Arca, Roser Solans-Laqué, Carlos Vázquez, Pau Lluch, Eva Salgado-Pérez, Cristina Luna-Gomez, J Francisco. Toyos Sáenz de Miera, Nagore FernándezLlanio, Antonio García, Carmen Larena, Natalia Palmou-Fontana, Vanesa CalvoRío, Carmen González-Vela, Alfonso Corrales, María Varela-García, Elena Aurrecoechea, Raquel Dos-Santos, José Luis Martín-Varillas, Sabela Fernández, J. Luis Hernández, Miguel A. González-Gay, Ricardo Blanco. Rheumatology, Internal Medicine and Pathology Units, Santander, Navarra, Madrid, Torrelavega, León, Pontevedra, Barcelona, Mondragón, Santiago de Compostela, Vigo, Alicante, Lugo, Badalona, Palencia, Alcázar de San Juan, A Coruña, Granada, Bilbao, Avilés, Castellón, Salamanca, Zaragoza, Valencia, Menorca, Málaga, Ávila, Gijón, Ourense, Tenerife, Sevilla, Lérida, Spain

Background: Aortitis can be idiopathic or associated with other conditions. It is frequently refractory to conventional immunosuppressive therapy. Tocilizumab (TCZ), an anti-IL-6 receptor antibody seems to be effective and safe.

Objectives: Our aim was to assess the efficacy and safety of TCZ at short and long follow-up in a series of patients with Aortitis.

Methods: Retrospective, multicenter study of 79 patients diagnosed of inflammatory aortitis based on imaging techniques (PET/CT, CT angiography and/or MR angiography).

Results: We study 79 patients $(61 \mathrm{w} / 18 \mathrm{~m}) .59(74.7 \%)$ cases were Aortitis secondary to Giant Cell Arteritis (GCA), while 20 (25.3\%) were idiopathic. The mean age was $71 \pm 8.5$ years vs $64.2 \pm 7.1$ years, respectively $(p=0.001)$. At time of disease diagnosis more than a half of patients $(59.5 \%)$ presented as main symptom polymyalgia rheumatica (PMR). Aortitis was diagnosed with PET/CT (71 patients), angioRMN (12 patients) and angioCT (8 patients). Prior to TCZ treatment, 61 (77.2\%) patients had received conventional immunosuppressive drugs, 59 (74.7\%) of them received MTX. After 24 months of treatment with TCZ, more than $75 \%$ of patients reached a prolonged remission in both groups $(p=0.527)$, with only $4 \%$ of relapses after the same follow-up period $(p=1.000) .40(50.6 \%)$ patients had a control image technique (PET/CT) throughout follow up. 4 ( 3 secondary to GCA and 1 idiopathic) patients reached a complete improvement in uptake after one year of treatment. Conclusion: Our results show that idiopathic aortitis occurs in younger patients compared with aortitis secondary to GCA. TCZ proved to be effective in both pathologies, allowing clinical and analytical improvement, as well as a reduction of corticoid dose, without increasing the risk of relapse. However, the improvement in imaging techniques seems to be slower.

\section{REFERENCE}

[1] Loricera J, Blanco R, Castañeda S, Humbría A, Ortego-Centeno N, Narváez J, et al. Tocilizumab in refractory aortitis: study on 16 patients and literature review. Clin Exp Rheumatol. 2014; 32:79-89.

TABLE

\begin{tabular}{|l|c|c|c|}
\hline & $\begin{array}{c}\text { Idiopathic aortitis } \\
(\mathbf{n = 2 0 )}\end{array}$ & $\begin{array}{c}\text { Aortitis secondary } \\
\text { to GCA } \\
(\mathbf{n = 5 9 )}\end{array}$ & $\mathbf{p}$ \\
\hline EFFICACY OF TCZ & & & \\
\hline Prolonged remission, $\mathrm{n}(\%)$ & $5(41.7)$ & $23(45.1)$ & 0.830 \\
Month 6 & $5(45.5)$ & $14(41.2)$ & 0.803 \\
Month 12 & $3(75)$ & $18(85.7)$ & 0.527 \\
\hline Month 24 & $2(15.4)$ & $1(3.3)$ & 0.213 \\
\hline Relapses, $n$ (\%) & $2(16.7)$ & $5(10.4)$ & 0.546 \\
Month 1 & $1(9.1)$ & $8(16.3)$ & 0.544 \\
Month 3 & $1(9.1)$ & $4(11.8)$ & 1.000 \\
Month 6 & 0 & $1(4.8)$ & 1.000 \\
Month 12 & & & \\
Month 24 & & &
\end{tabular}

Disclosure of Interests: Monica Calderón-Goercke: None declared, J. Loricera: None declared, D. Prieto-Peña: None declared, Vicente Aldasoro: None declared, Santos Castañeda Consultant for: Amgen, BMS, Pfizer, Lilly, MSD, Roche, Sanofi, UCB, Ignacio Villa-Blanco: None declared, Alicia Humbría: None declared, Clara Moriano: None declared, Susana Romero-Yuste: None declared, J. Narváez Consultant for: Bristol-Myers Squibb, Catalina Gomez-Arango: None declared, Eva Perez-Pampín: None declared, Rafael Melero: None declared, Marcelino Revenga: None declared, Noelia Alvarez-Rivas: None declared, Francisca Sivera: None declared, María Álvarez del Buergo: None declared, Luisa Marena Rojas: None declared, Eva Galindez: None declared, Beatriz Arca: None declared, Roser Solans-Laqué: None declared, Carlos Vázquez: None declared, Pau Lluch: None declared, Eva Salgado-Pérez: None declared, Cristina Luna-Gomez: None declared, Francisco J. Toyos Sáenz de Miera: None declared, Nagore Fernández-Llanio: None declared, Antonio García: None declared, Carmen Larena: None declared, Natalia PalmouFontana: None declared, Vanesa Calvo-Río: None declared, Carmen González-Vela: None declared, Alfonso Corrales: None declared, María Varela-García: None declared, Elena Aurrecoechea: None declared, Raque Dos-Santos: None declared, José Luis Martín-Varillas: None declared, Sabela Fernández: None declared, J. Luis Hernández: None declared, Miguel A González-Gay Grant/research support from: Prof. MA GonzalezGay received grants/research supports from Abbvie, MSD, Jansen and Roche., Speakers bureau: Consultation fees/participation in company sponsored speaker's bureau from Pfizer, Lilly, Sobi, Celgene, Novartis, Roche and Sanofi., Ricardo Blanco Grant/research support from: Abbvie, MSD and Roche, Consultant for: Abbvie, Pfizer, Roche, Bristol-Myers, Janssen, Speakers bureau: Abbvie, Pfizer, Roche, Bristol-Myers, Janssen DOI: 10.1136/annrheumdis-2019-eular.3571

\section{SAT0221 OFF-LABEL USE OF BIOLOGICAL THERAPIES IN RELAPSING AND/OR REFRACTORY POLYARTERITIS NODOSA}

Alice Canzian ${ }^{1}$, Omer Karadag ${ }^{2}$, Anne Contis ${ }^{3}$, Francois Maurier ${ }^{4}$, Silvia Sartorelli ${ }^{5}$ Laure Denis $^{6}$, Sebastien Sanges ${ }^{7}$, Claire De Moreuil ${ }^{8}$, Cécile-Audrey Durel ${ }^{9}$, Stephane Durupt ${ }^{9}$, Marie Jachiet ${ }^{10}$, Diane Rouzaud ${ }^{10}$, Carlo Salvarani ${ }^{11}$, Franco Schiavon ${ }^{12}$, Lorenzo Dagna ${ }^{5}$. Fabrice Bonnet ${ }^{3}$, David Jayne ${ }^{13}$,

Loïc Guillevin ${ }^{14}$, Benjamin Terrier ${ }^{15}$. 'University of Parma, Parma, Italy; ${ }^{2}$ Hacettepe University, Ankara, Tunisia; ${ }^{3} \mathrm{CHU}$ de Bordeaux, bordeaux, France; ${ }^{4}$ Private Metz Hospital, Metz, France; ${ }^{5}$ RCCS San Raffaele Hospital, Milan, Italy; ${ }^{6} \mathrm{CHU}$ de Clermont-Ferrand, Clermont-Ferrand, France; ${ }^{7} \mathrm{CHU}$ de Lille, Lille, France; ${ }^{8} \mathrm{CHU}$ de Brest, Brest, France; ${ }^{9} \mathrm{CHU}$ de Lyon, Lyon, France; ${ }^{10}$ Paris, Paris, France; ${ }^{11}$ Università de Modena e Reggio Emilia, Reggio Emilia, Italy, ${ }^{12}$ University of Padova, Padova, Italy, ${ }^{13}$ University of Cambridge, Cambridge, United Kingdom; ${ }^{14}$ Université Paris Descartes, Paris, France; ${ }^{15}$ Paris Descartes University, Paris, France

Background: Polyarteritis nodosa (PAN) is a rare systemic necrotizing vasculitis of medium- and small-sized arteries, not associated with antineutrophil cytoplasmic antibodies (ANCA). Conventional treatments include glucocorticoids (GCs) for non-severe disease and a combination of GCs and immunosuppressive agents for severe disease. Nevertheless, some patients have refractory and/or relapsing disease.

Objectives: We examined the use of off-label biological therapy for relapsing/refractory PAN.

Methods: This retrospective European collaborative study included patients with PAN meeting ACR criteria and/or Chapel Hill Consensus Conference 2012 definitions. Treatment efficacy and safety are recorded. Remission was defined as the absence of vasculitis manifestations (BVAS $=0$ ) with a prednisone dose $\leq 5 \mathrm{mg} /$ day. Partial response was defined as a BVAS $=0$ with a prednisone dose between 6 and $10 \mathrm{mg} /$ day.

Results: Fifty-one patients (24 men, 27 women; median age 51 years) were included. Eighteen (35\%) patients received TNF-alpha blockers, 16 (31\%) received rituximab (RTX), $9(18 \%)$ tocilizumab (TCZ), and $8(16 \%)$ other biologics (including alemtuzumab in 3 , anakinra in 2 , interferonalpha in 2 and abatacept in one). Previous treatments were: GCs in all cases, including methylprednisolone infusions $(72 \%)$ and oral GCs $(92 \%)$, cyclophosphamide $(61 \%)$, azathioprine $(53 \%)$, methotrexate $(45 \%)$ and mycophenolate mofetil (47\%). At inclusion, median BVAS was 5 (range $0-18)$, including $5(2-12)$ in the TNF-alpha blockers group, 5 (2-12) in the RTX group and 4 (0-6) in the TCZ group.

After median follow-up of 34.4 months (IQR 21.5-59.5), remissions, partial responses and treatment failure, respectively, were noted in $41 \%, 6 \%$ and $53 \%$ for TNF-alpha blockers recipients, $25 \%, 12 \%$ and $63 \%$ for RTX recipients, and $57 \%, 0 \%$ and $43 \%$ for TCZ recipients. No remission was noted in patients treated with anakinra, alemtuzumab and abatacept. Median BVAS dropped to 3 at 6 months, 0 at 12 months and 0 at last follow-up in the TNF-alpha blockers group, to $3.5,0$ and 2 in the RTX group, respectively, and 0,0 and 0 in the TCZ group. A GC-sparing effect seemed more important with TNF-alpha blockers and TCZ. Median GCs dose decreased from the baseline $15 \mathrm{mg} /$ day to 10 at 6 months, 5 at 12 months and 5 at last follow-up in the TNF-alpha blockers group, from $15 \mathrm{mg} /$ day to 10 at 6 months, 5 at 12 months and 10 at last follow-up in the RTX group, and from $15 \mathrm{mg} /$ day to 7 at 6 months, 5 at 12 months and 5 at last follow-up in the TCZ group.

Four (22\%) patients stopped TNF-alpha blockers because of allergic reaction in one and refractory disease in 3 . Six $(38 \%)$ stopped RTX because of refractory disease. Finally, $4(44 \%)$ stopped TCZ because of adverse 